Kolmakova, A.S. (2022). Budget analysis of the City of Nizhny Novgorod. International collection of the student works on Jurisprudence. Tuculart Student Scientific, 1 (1), 19-28. Ostrava: Tuculart Edition.

$$
\text { DOI: } 10.47451 / \text { tss2022-01-02 }
$$

The paper will be published in Crossref, Internet Archive, ICI Copernicus, Google Scholar, Academic Resource Index ResearchBib, J-Gate, International Scientific Indexing (ISI), eLibrary databases.

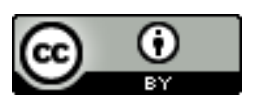

Anastasia S. Kolmakova, Bachelor Student, Department of State and Legal Disciplines, Faculty of training specialists for the judicial system, Russian State University of Justice, St Petersburg, Russia.

Scientific supervisor: Nina N. Gontar, Candidate of Sciences, Associate Professor of the Department, Department of State and Legal Disciplines, Russian State University of Justice, St Petersburg, Russia.

\title{
Budget analysis of the City of Nizhny Novgorod
}

Abstract: The relevance of the work is very significant. It is because the activities, which realised to increase the level of budget information openness and the local governments' activities transparency involved in the preparation, execution of the city budget and budget reporting, allows us to get feedback from citizens who are interested in the development of municipal finance and create conditions for public control of municipal financial management. The study purpose is to consider the execution of the federation subject's budget on the example of the City of Nizhny Novgorod. The methodological basis of the study is statistical reports on the Nizhny Novgorod budget execution. The logical, dialectical, comparative legal method was used in the study. Other general logical methods were also used, such as analysis and synthesis, abstraction and generalization, deduction and induction, analogy. The practical significance of the work lies in the fact that the results obtained during the study can be used to solve various issues of the legitimate use of financial legislation.

Keywords: Nizhny Novgorod, budget execution, municipal budget, budget parameters, city budget expenditure structure.

Анастасия Сергеевна Коммакова, студент 4 курса, кафедра государственно-правовых Аисциплин, факультет подготовки специалистов Аля судебной системы, Российский Государственный университет правосудия, Санкт-Петербург, Россия.

Научный руководитель: Нина Николаевна Гонтарь, кандиАат наук, доцент кафеАры кафедра государственно-правовых Аисциплин, Российский Государственный университет правосудия, Санкт-Петербург, Россия.

\section{Анализ бюджета Нижнего Новгорода}

Аннотащия: Актуальность работы весьма значительна и обусловлена тем, что мероприятия, проводимые по повышению уровня информационной открытости бюджета и прозрачности Аеятельности органов местного самоуправления, принимающих участие в подготовке, исполнении бюджета города и составлении бюджетной отчетности, позволяют получить обратную связь от граждан, которым интересны вопросы развития муниципальных финансов, и создать, таким образом, условия Аля общественного контроля в сфере муниципального управления финансами. Целью исследования является рассмотрение исполнения бюджета субъекта федерации на примере города Нижний Новгород. Методологическую основу 
исследования составляют статистические отчеты об исполнении бюджета города Нижний Новгород. При проведении исследования применялись Аогический, Аиалектический, сравнительно-правовой метод. Использовались также и другие общелогические методы, такие как: анализ и синтез, абстрагирование и обобщение, Аедукция и инАукция, аналогия. Практическая значимость работы заключается в том, что полученные в ходе исследования результаты могут быть использованы при решении различных вопросов правомерного использования финансового законодательства.

Ключевые слова: Нижний Новгород, исполнение бюджета, бюджет муниципальных образований, параметры бюджета, структура расходов городского бюджета.

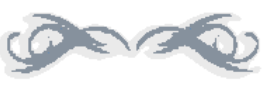

\section{Introduction}

One of the most important directions of the budgetary and tax policy of the Nizhny Novgorod City District municipality is to ensure the openness and transparency of public finances.

The topic relevance is very significant because the activities carried out to increase the level of information openness of the budget and transparency of the local governments' activities involved in the preparation, execution of the city budget and budget reporting, allows us to get feedback from citizens who are interested in the municipal finance development and create conditions for public control of municipal financial management.

The study object of the study is the city of Nizhny Novgorod.

The study subject is the Russian Federation subject's budget.

The study purpose is to consider the execution of the Russian Federation subject's budget on the example of the City of Nizhny Novgorod.

Based on the purpose of the study, the following tasks were formulated:

- make an overview of the priority areas of budget and tax policy of Nizhny Novgorod;

- analyze the main parameters of the budget of the city of Nizhny Novgorod;

- $\quad$ assess the structure of the budget expenditures of the city of Nizhny Novgorod.

The methodological basis of the study is statistical reports on the execution of the budget of the city of Nizhny Novgorod. The logical, dialectical, comparative legal method was used in the study. Other general logical methods were also used such as analysis and synthesis, abstraction and generalization, deduction and induction, analogy.

The practical significance of the work lies in the fact that the results obtained during the study can be used to solve various issues of the legitimate use of financial legislation.

\section{Main tasks and priority directions of budget and tax policy}

The Tax Policy Budget of the Nizhny Novgorod City District is aimed at improving the efficiency of management in municipal property, sustainable economic growth, improving the social sphere, increasing tax potential and achieving other priority goals of social and economic development of the city district, taking into account the current economic situation, through effective, responsible and transparent management of public finances (Vasilishina, 2020). Thus, according to the Information Collection "Budget for Citizens", referred to as On the Nizhny Novgorod 
Budget for 2021 and the Planning Period 2022-2023, posted on the official website of the City of Nizhny Novgorod, priority areas of budget and tax policy of this municipality include:

1. Preservation and development of tax potential on the territory of the city.

2. Mobilization of city budget revenues through effective administration of local taxes and increasing the collection of taxes received by the city budget.

3. Implementation of tax policy taking into account the optimization of tax benefits for local taxes based on the assessment of tax expenditures;

4. Ensuring the stability of the taxation system for legal entities and individuals, improving regulatory legal acts on taxes adopted by local self-government bodies, taking into account changes in federal legislation.

5. Carrying out measures to improve the efficiency of municipal property management.

6. Ensuring the balance and long-term sustainability of the city budget through the formation of a realistic revenue forecast based on the forecast of social and economic development of the city for 2021 and the planning period of 2022 and 2023, a balanced approach to the adoption of new spending commitments, responsible debt policy.

7. Improving the efficiency and optimization of budget expenditures through an integrated approach to the development of strategic decisions, prioritization of expenditures, increasing the share of program expenditures in the total volume of city budget expenditures, improving the quality of program budgeting based on planned and achieved results, strengthening the control of financial discipline of functional (branch) divisions based on monitoring the implementation of municipal programs;

8. Improving the quality of municipal services provided.

9. Improving the efficiency of municipal management by improving the tools of program and target planning, developing project management mechanisms, improving the quality of financial management in city institutions, implementing the principles of openness and transparency of municipal finance management, disclosure of financial and other information about the budget and the budget process, the introduction of the principles of initiative budgeting.

10. Development and improvement of financial control and control systems in procurement (On the Nizhny Novgorod Budget for 2021 and the Planning Period 2022-2023).

\section{The main parameters of the budget of the City of Nizhny Novgorod}

The budget of the Nizhny Novgorod municipal district for 2021 was initially approved of 36.5 million rubles with a budget deficit of 0.3 million rubles (The Law of the Niøhny Novgorod Region "On the Regional Budget for 2021'). At the same time, the expenses of the city were originally planned to increase by $15 \%$ and amount to 36.8 million rubles. In the course of budget execution, during the reporting year, the planned budget indicators amounted to (-299.1 million rubles), i.e., they did not go beyond the planned budget. The total revenues received by the budget of the Nizhny Novgorod Municipal District amounted to 36.554.9 million rubles from the initial plan (36.5 million rubles), i.e., 100.13\%. The total expenses of the Nizhny Novgorod Municipal District amounted to $36,835,9$ million rubles from the initial plan (36,8 million rubles), i.e., 100.03\% (Fig. 1, 2).

In 2021, the volume of Nizhny Novgorod's income amounted to 15,909.7 million rubles, 
and the gratuitous receipts were 20645.2 million rubles.

For 2021, the volume of Nizhny Novgorod's expenses amounted to 16,208.7 million rubles. The share of program expenditures in the structure of budget expenditures is $93.9 \%$. The general expenses will be directed to the implementation of municipal programs:

1) Development of education - 19,045.5 million rubles;

2) Improvement of the city $-3,493.8$ million rubles;

3) Development of road infrastructure $-3,067.1$ million rubles;

4) Development of culture $-2,405.7$ million rubles;

5) Municipal finance management - 1,436.8 million rubles;

6) Development of physical culture and sports - 1084.6 million rubles (On the Budget of the City of Nizhny Novgorod for 2021 and for the Planning Period 2022-2023).

Thus, the leading share of expenditures in the budget of Nizhny Novgorod in 2021 was the education development and city improvement, as in 2019-2020.

\section{The structure of the budget expenditures of the City of Nizhny Novgorod}

As in the previous period, the financing of social expenditures (education, social policy, culture and sports) was a priority, for which from 2019 to 2020, 50\% to 55.5\% of total expenditures were allocated, in 2021 the share of social expenditures was $55.5 \%$ or $20,453.9$ million rubles. (fig. 3, 4)

\section{Expenses under the Education Section}

In the Education sector, the expenditures of the city district budget for 2021 were executed in the total amount of 19,045,538,409.85 million rubles, i.e., $51.6 \%$ of the total expenses of the municipality (Open Budget of the City of Nishny Novgorod).

The target areas of the financing were:

1. Satisfaction of the population with the quality of preschool education from the total number of parents surveyed, whose children attend preschool education organizations in the corresponding year - 97\%.

2. Satisfaction of consumers (parents, children) with the quality of general education services $-97 \%$.

3. The share of municipal educational organizations that meet modern educational requirements in the total number of municipal educational organizations $-100 \%$.

4. Availability of preschool education for children aged 1 to 3 years $-100 \%$.

5. The share of municipal preschool educational organizations providing additional services $70 \%$.

6. The percentage of coverage of children aged 3-7 years who want to receive preschool education services in basic general education programs $-100 \%$.

7. The ratio of the average monthly salary of teachers of municipal educational organizations of preschool education to the average salary in the general education of the region $-100 \%$.

8. The share of citizens (parents) who have received social support in the form of compensation for part of the parental fee for the supervision and care of children who have applied and are eligible to receive this support $-96 \%$.

9. The share of municipal preschool educational organizations whose buildings are in disrepair 
or require major repairs in the total number of municipal preschool educational organizations $-0 \%$.

10. The share of preschool educational organizations providing unhindered access to disabled people and other low-mobility groups of citizens $-95 \%$.

11. The share of preschool educational organizations providing the creation of material, technical and methodological conditions for the implementation of inclusive education $50 \%$.

12. The ratio of the average monthly salary of teachers of municipal educational organizations to the average salary in the region $-100 \%$.

13. The share of coverage of hot meals for students of educational institutions $-92 \%$.

14. The share of municipal educational organizations whose buildings are in disrepair or require major repairs in the total number of municipal educational organizations $-0 \%$.

15. The share of students in municipal educational organizations engaged in the second shift in the total number of students in municipal educational organizations $-7 \%$.

16. The share of general education organizations providing unhindered access to disabled people and other low-mobility groups of citizens in the total number of general education organizations $-33.7 \%$.

17. The share of children aged 5 to 18 years receiving additional education services in the total number of children aged 5 to 18 years $-84.5 \%$.

18. The coverage of students in educational organizations of the city with organized forms of recreation, recreation and employment of children for one calendar year $-100 \%$.

19. The share of teachers who have received the first and highest qualification categories following the established procedure and confirmation of compliance with their position in the total number of teachers of municipal organizations of general education $-34 \%$.

20. Provision of accounting, tax and statistical reporting - 501 institutions.

21. The proportion of children orphans and children left without parental care, entrusted to the care of families of citizens in the city, from among children orphans and children left without parental care identified during the reporting period $-75 \%$.

22. The proportion of children orphans and children left without parental care, returned from foster families from the total number of children orphans and children left without parental care, placed with families of citizens for the period $-0.5 \%$.

Expenditures under the preschool education development subprogram amounted to 6,962,117,288.62 million rubles. Expenses under the program Development of General Education were 7,735,548,443.15 rubles. Interestingly, the budget did not contain expenses for providing an accessible environment for children with disabilities in general education organizations.

\section{Expenses in Urban Improvement}

In the field of urban improvement, the total amount of expenditures amounted to 3,493,837,097.30 million rubles or 9.4\% (Open Budget of the City of Nir.hny Novgorod).

The target areas of the financing were:

1. The share of the city's population satisfied with the quality of urban improvement (in the total number of citizens surveyed) $-60 \%$. 
2. The share of landscaping objects that are in a normative state according to the total number of landscaping objects $-41 \%$.

3. The share of municipal cemeteries that are in a normative state according to the total number of municipal cemeteries $-65 \%$.

4. Coverage of rain sewer networks $-85 \%$.

5. The share of repaired storm sewer networks of the city according to the total number of storm sewer networks requiring repair $-3.6 \%$.

6. The share of engineering protection structures of the city that meet regulatory requirements $-95 \%$.

7. The share of repaired objects of engineering protection of the city according to the total number of objects of engineering protection of the city requiring repair $-1 \%$.

8. The share of repaired other improvement objects to the total number of other improvement objects $-78 \%$.

Expenses under the greening program of the city amounted to 149,169,700.00 million rubles. The organization and maintenance of burial sites in the city of Nizhny Novgorod contained expenses in 30,072,000,00 rubles. Expenses for other improvement facilities (including storm sewer networks and engineering protection structures) of the city of Nizhny Novgorod amounted to $9,657,800.00$.

\section{Expenses for the Nizhny Novgorod 800th Anniversary Preparation project}

The total financing for preparations for the Nizhny Novgorod 800th Anniversary celebration in 2019-2021 amounts to 23.8 billion rubles. It became known at a meeting of the regional government, which was held today for the first time since December 2019. 12.8 billion rubles were raised from the federal budget, 7.9 billion rubles were directed from the regional budget, 181.8 million rubles were allocated by the budget of Nizhny Novgorod of the total amount of funds. Another 3 billion rubles came from extra-budgetary sources (Open Budget of the City of Nizhny Novgorod).

\section{Discussion}

As part of the study of the budget execution of regions and individual municipalities, it seems necessary to pay special attention to the trends in changes in individual items of expenditure and their correlation in the legal field of the Russian Federation. It is also necessary to have a clear understanding of the permissible limits of execution and non-execution of the budget of a constituent entity of the Russian Federation to create an effective delta of variability that will contribute to a more flexible fiscal policy.

\section{Conclusion}

Summing up the work done, we can draw several definite conclusions.

According to the Budget Code of the Russian Federation, a budget is a form of formation and expenditure of a fund of funds intended for financial support of the tasks and functions of the state and local self-government (Budget Code of the Russian Federation). The budget process of the City of Nizhny Novgorod is the activity of state authorities and other participants in the budget process regulated by the legislation of the Russian Federation and the Nizhny Novgorod region 
for the preparation and review of draft budgets of the city of Nizhny Novgorod, draft budgets of the Territorial Compulsory Health Insurance Fund, approval and execution of budgets and budgets of the territorial state extra-budgetary fund, control over their execution, implementation of budget accounting, compilation, external audit, review and approval of budget reporting (Unified Accounting Policy for the Accounting Centralization, Applied in the Accounting (Budgeting) of Branch (Functional), Territorial Bodies of the Nizhny Novgorod Administration).

By the end of 2021, the largest share of the industry's expenditures falls on the implementation of municipal programs:

1) The Nizhniy Novgorod 800th Anniversary Preparation,

2) Development of Education in the City of Nizhny Novgorod,

3) Improvement of the City of Nizhny Novgorod.

The expenses of the Department of Culture in the preparation of the City of Nizhny Novgorod for the 800th anniversary amounted to 23.8 billion rubles, attracted by banknotes from the federal budget.

Expenses under the program Development of Education in the City of Nizhny Novgorod amounted to 19,045,538,409.85 million rubles, raised at the expense of the city's funds.

Expenses under the program Improvement of the City of Nizhny Novgorod amounted to $3,493,837,097.30$, raised at the expense of own funds and federal budget funds.

\section{References:}

The Constitution of the Russian Federation (adopted by popular vote on 12.12.1993) (with amendments approved during the all-Russian vote on 01.07.2020). Retrieved January 15, 2022, from http://www.consultant.ru/document/cons doc LAW 28399/ (in Russian)

Budget Code of the Russian Federation dated July 31, 1998, No. 145-FZ (edition of April 22 , 2020). Retrieved January 15, 2022, from http://www.consultant.ru/document/cons_doc_LAW_19702/(in Russian)

The Law of the Nizhny Novgorod Region "On the Regional Budget for 2021" dated December 17, 2020. (in Russian)

On the Budget of the City of Nizhny Novgorod for 2021 and for the Planning Period 20222023 (as amended on February 17, 2021) dated December 16, 2020 No. 88. The City Duma of the city of Nizhny Novgorod, Nizhny Novgorod region. Retrieved January 15, 2022, from https://docs.cntd.ru/document/571704365 (in Russian)

Open Budget of the City of Nizhny Novgorod. Retrieved January 15, 2022, from http://бюАжетнн.pф/ (in Russian)

Unified Accounting Policy for the Accounting Centralization, Applied in the Accounting (Budgeting) of Branch (Functional), Territorial Bodies of the Nizhny Novgorod Administration. Retrieved January 15, 2022, from https://docs.google.com/viewer?url=http $\% 3 \mathrm{~A} \% 2 \mathrm{~F} \% 2 \mathrm{Fxn}--90 \mathrm{agdd} 0 \mathrm{ba} 7 \mathrm{a} 0 \mathrm{~g} . \mathrm{xn}-\mathrm{-}$ p1ai $\% 2$ Findex.php $\% 3$ Foption $\% 3$ Dcom_dropfiles $\% 26$ task $\% 3$ Dfrontfile.download $\% 26 \% 2$ 6id\%3D 914\%26catid\%3D327\%26token\%3Db65e96c1aa35d908949b7d507ab78b02\%26p review $\% 3$ D1\&embedded=true (in Russian) 
Order on Approval of the Accounting Policy of the Central Bank of the Russian Federation 2021. No. 201 dated December 31, 2020. Retrieved January 15, 2022, from https://docs.google.com/viewer?url=http $\% 3 \mathrm{~A} \% 2 \mathrm{~F} \% 2 \mathrm{Fxn}--90 \mathrm{agdd} 0 \mathrm{ba} 7 \mathrm{a} 0 \mathrm{~g} . \mathrm{xn}-\mathrm{-}$

p1 ai $\% 2$ Findex.php $\% 3$ Foption $\% 3$ Dcom dropfiles $\% 26$ task $\% 3$ Dfrontfile.download $\% 26 \% 2$ 6id\%3D 915\%26catid\%3D327\%26token\%3Db65e96c1aa35d908949b7d507ab78b02\%26p review\%3D1\&embedded=true (in Russian)

Resolution of the Administration of the City of Nizhny Novgorod No. 4940 dated November 9, 2021, "On the Execution of the Budget of the City of Nizhny Novgorod for 9 months of 2021". Retrieved January 15, 2022, from https://docs.google.com/viewer?url=http $\% 3 \mathrm{~A} \% 2 \mathrm{~F} \% 2 \mathrm{Fxn}--90 \mathrm{agdd} 0 \mathrm{ba} 7 \mathrm{a} 0 \mathrm{~g} . \mathrm{xn}-\mathrm{-}$ p1ai $\% 2$ Findex.php $\% 3$ Foption $\% 3$ Dcom dropfiles $\% 26$ task $\% 3$ Dfrontfile.download $\% 26 \% 2$ 6id \%3D1068\%26catid \%3D280\%26token \%3Db65e96c1aa35d $908949 \mathrm{~b} 7 \mathrm{~d} 507 \mathrm{ab} 78 \mathrm{~b} 02 \% 26$ preview $\% 3 \mathrm{D} 1 \&$ embedded=true (in Russian)

Decision of the City Duma "On the Execution of the Budget of the City of Nizhny Novgorod for 2020”. Retrieved January 15, 2022, from http:/ бюджетнн.pф/dokumenty\#192-2020god

Vasilishina Yu. (2020, December 16). The Nizhny Novgorod Budget for 2021: what money from the state treasury will be spent on. Retrieved January 15, 2022, from: https://www.nnov.kp.ru/daily/21712100/4339593/(in Russian) 


\section{Appendix}

\begin{tabular}{|c|c|c|c|}
\hline Parameters & 2021 & 2022 & 2023 \\
\hline Total income & 36554,9 & 34633,3 & 34405,0 \\
\hline own income & 19909,7 & 16625,2 & 17718,4 \\
\hline gratuitous receipts & 20645,2 & 18008,1 & 16686,6 \\
\hline Total expenses & 36853,9 & 34633,3 & 34342,0 \\
\hline own expenses & 16208,7 & 16625,2 & \\
\hline Deficit / Surplus & $-299,0$ & 0,0 & 63,0 \\
\hline
\end{tabular}

Figure 1. The main parameters of the Nizhny Novgorod budget for 2021-2023, million rubles

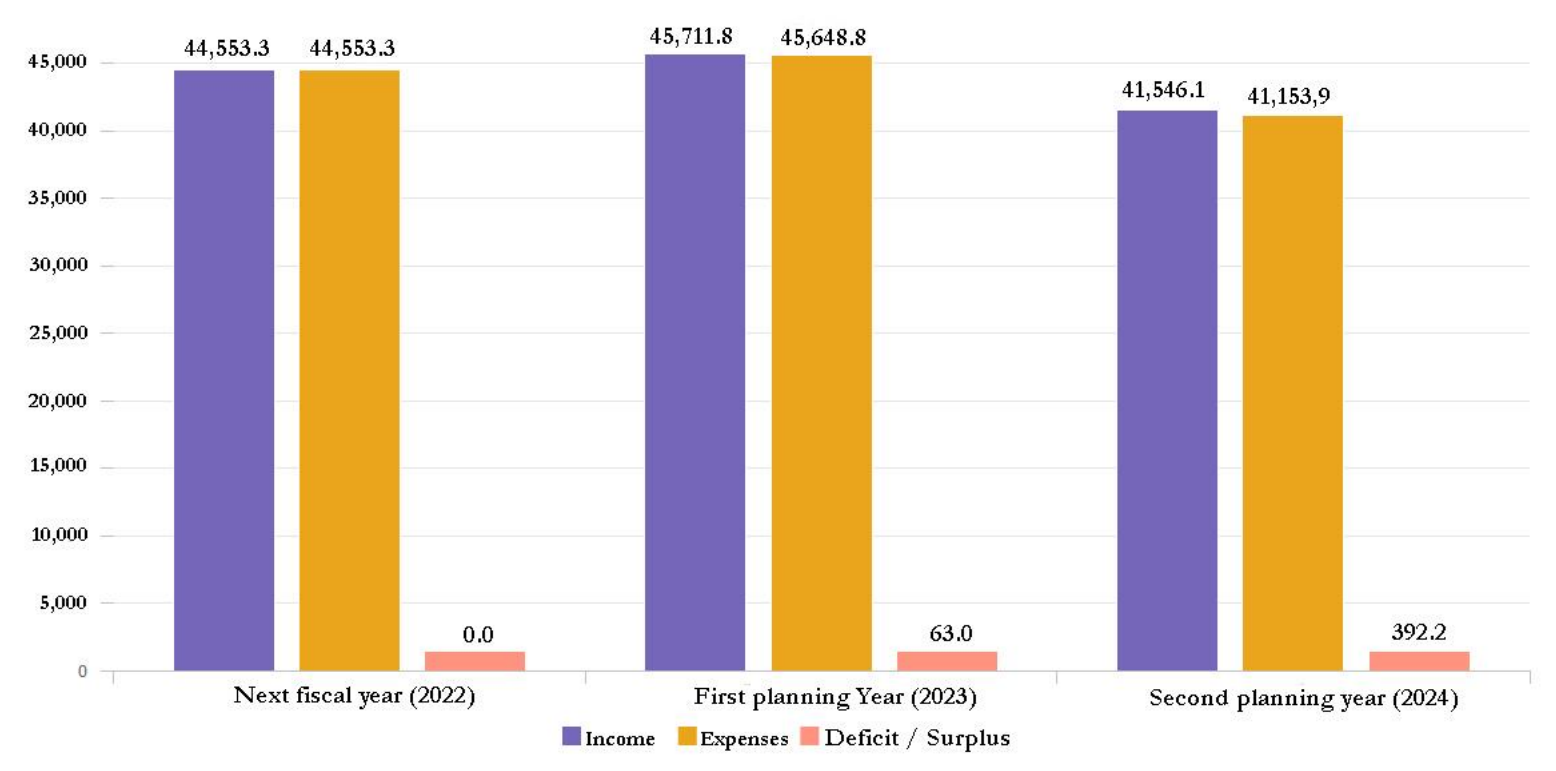

Figure 2. The main parameters of the budget of the City of Nizhny Novgorod 

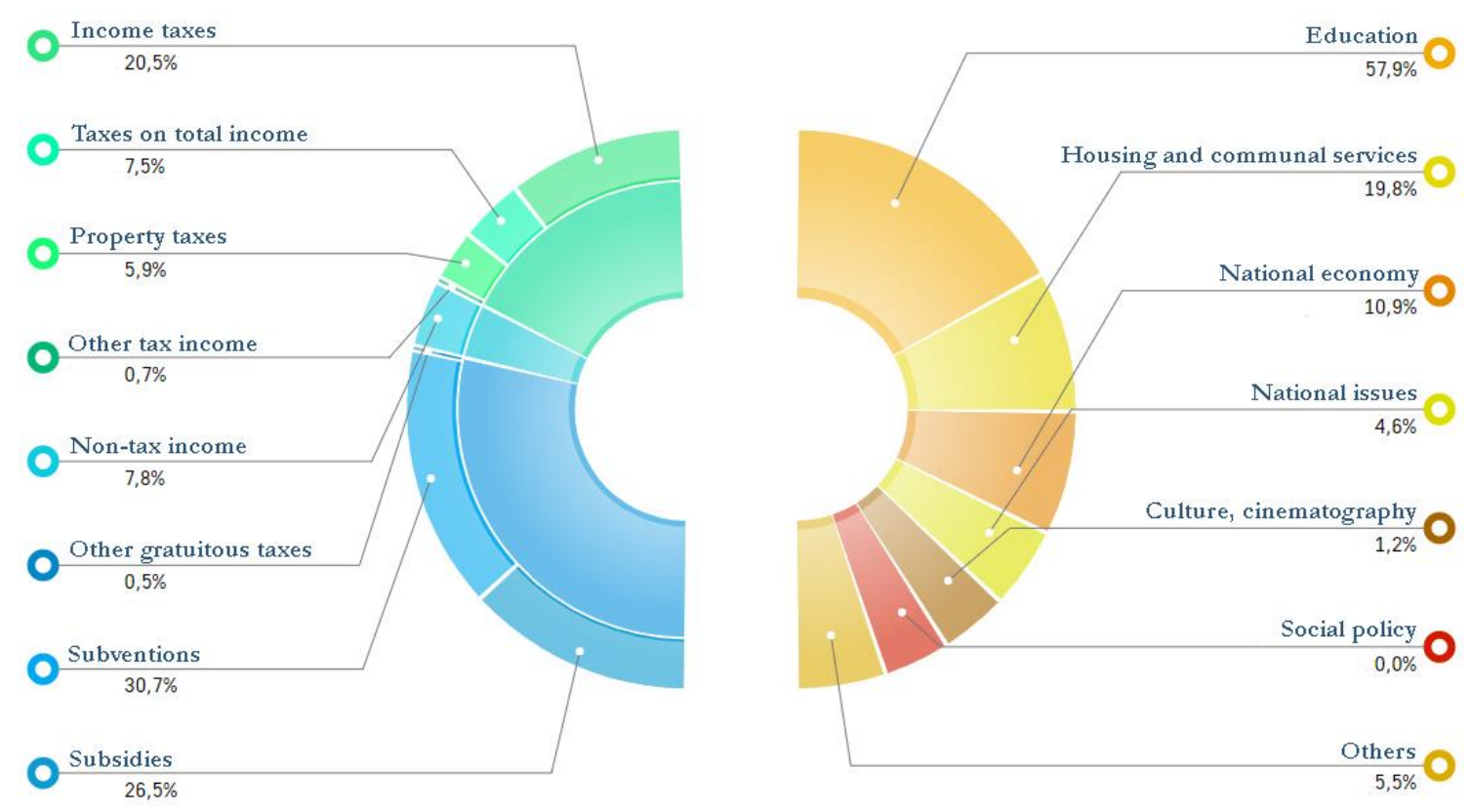

Figure 3. The structure of expenditures of the Nizhny Novgorod budget for 2021
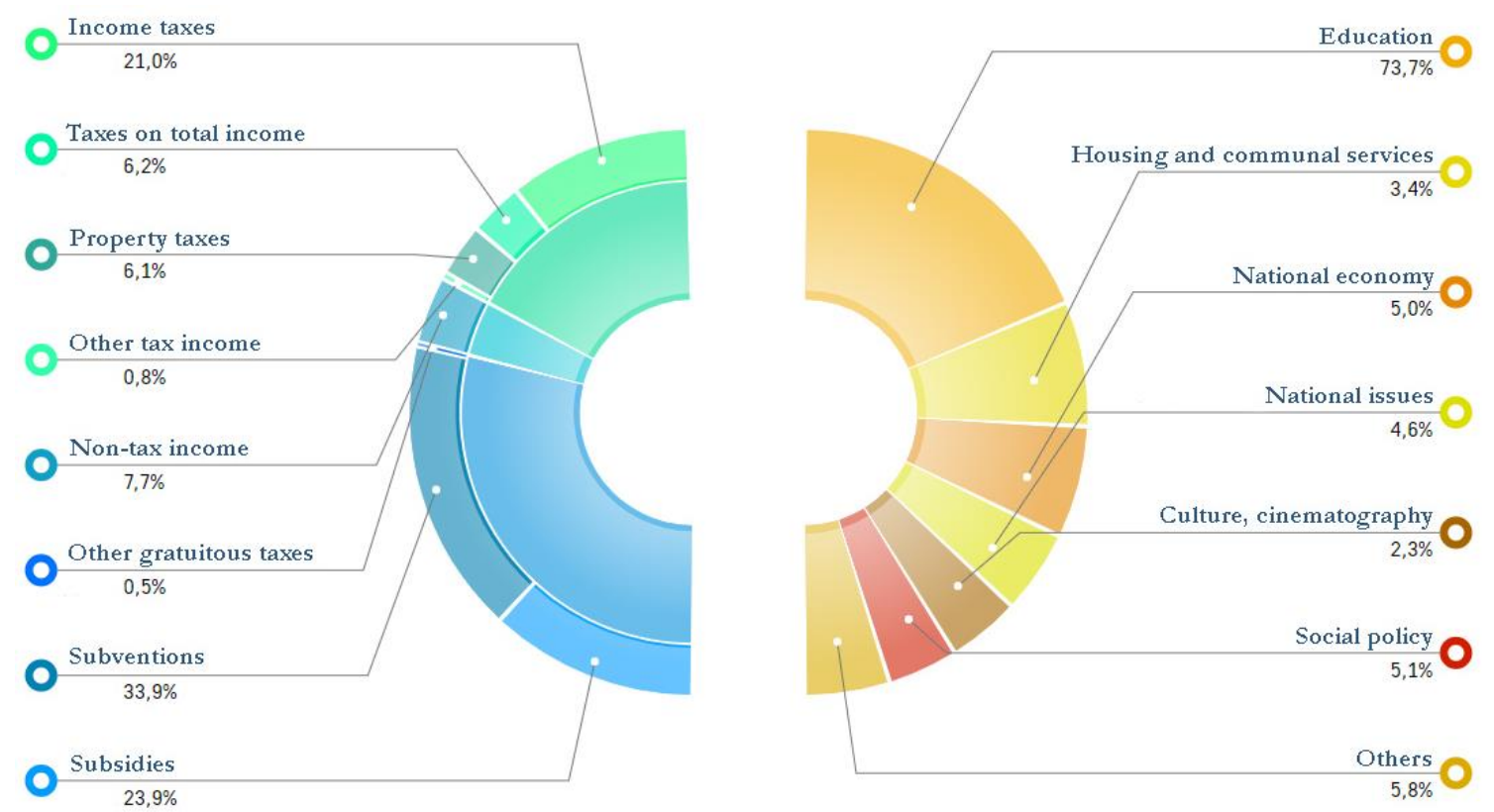

Figure 4. The structure of expenditures of the Nizhny Novgorod budget for 2022 


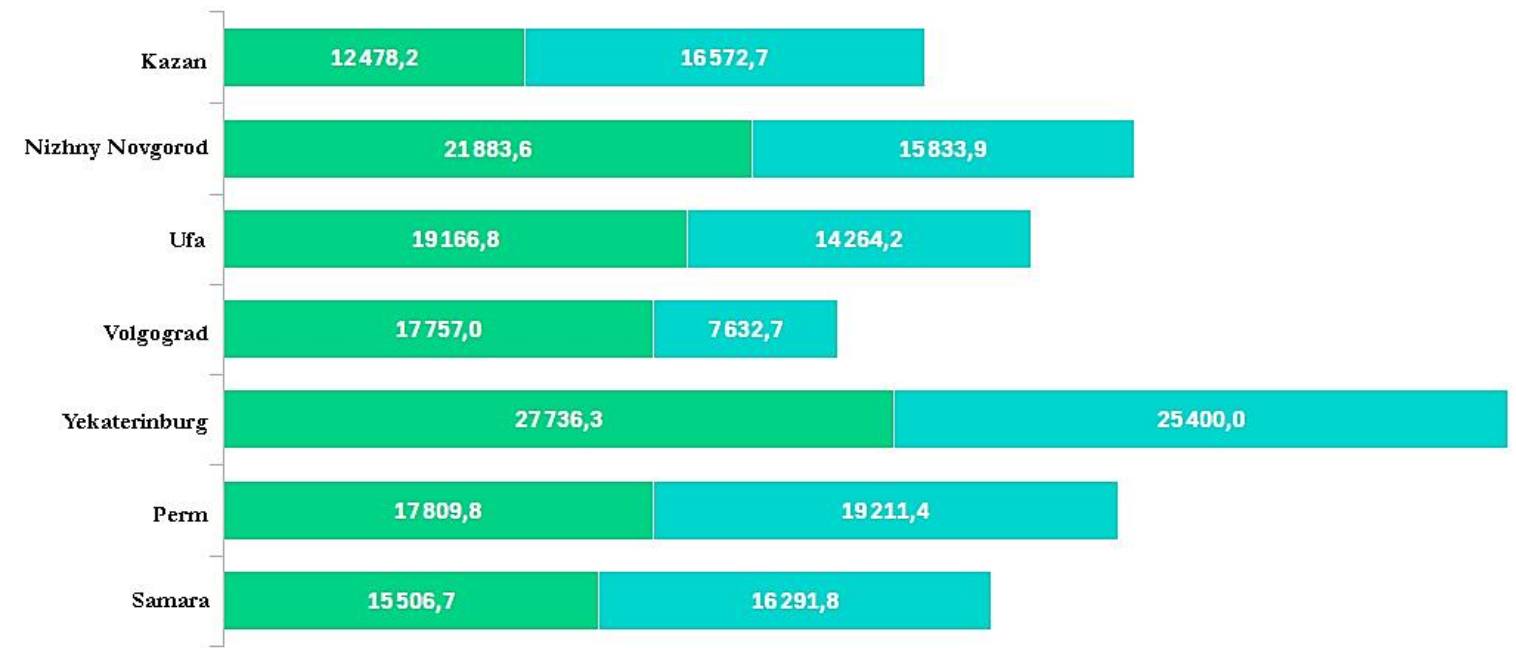

Figure 5. Comparison of budget revenues of million-plus cities for 2020 